\title{
KEBIJAKAN TRANSPARANSI DAN AKUNTABILITAS: MAMPUKAH MENCEGAH PENYELEWENGAN DANA DESA?
}

\author{
Intan Rakhmawati \\ Universitas Mataram \\ (intanrakhmawati@unram.ac.id)* \\ Raden Sapto Hendri, BS \\ Universitas Mataram \\ (saptohendri99@unram.ac.id) \\ Nungki Kartikasari \\ Universitas Mataram \\ (nungkikartikasari@unram.ac.id)
}

Disubmit: 7 Januari 2021

Mulai Review: 1 Februari 2021

Selesai Review: 22 Mei 2021

Diterima: 7 Juni 2021

\begin{abstract}
Transparency and accountability of village finances are highlighted topics, because of potential fraud that has occurred. Even though village finance uses Siskeudes and the village government is covered by 4 ministries. Not to mention planning and budgeting which must be linked to BPS data and the Ministry of Social Affairs, due to budget reallocation for Direct Cash Assistance (BLT). This research use phenomenology analytical descriptive for analyze transparency and accountability policies of the 4 ministries, with the perspective of the district DPMD. As a result, the researchers concluded that the accountability regulations from the Ministry of Home Affairs, the Ministry of PDTT, and the Ministry of Finance were quite integrated. Its derivative is the Priority Regulation for the Using of Village Funds from Ministry of PDTT. The allocation and reallocation of expenditure must also be followed by a Regent Regulation. Its integration in Village Financial System (Siskeudes) from BPKP and the Village Development Information System (SiPeDe) of the Ministry of PDTT, are sufficient to minimize mistakes and the potential for fraud. Unfortunately its less supported by transparency regulation for evaluation, from Ministry of Communication and Information.
\end{abstract}

Keywords: Transparency, Accountability, Regulatory Convergence, Prevention of Village Fund Fraud.

\begin{abstract}
Abstrak
Transparansi dan akuntabilitas keuangan desa merupakan topik yang disorot, karena potensi kecurangan yang terjadi. Padahal keuangan desa menggunakan Siskeudes, dan pemerintah desa dinaungi 4 kementerian. Belum lagi perencanaan dan penganggaran yang harus terkait dengan data BPS dan Kementerian Sosial, karena realokasi anggaran untuk Bantuan Langsung Tunai (BLT). Penelitian ini menggunakan metode deskriptif analitis kebijakan untuk menganalisis transparansi dan akuntabilitas dari 4 kementerian, dengan perspektif DPMD kabupaten. Hasilnya, peneliti menyimpulkan antar peraturan akuntabilitas dari Kemendagri, Kemendes PDTT, dan Kementerian Keuangan cukup terintegrasi. Turunannya yaitu Peraturan Prioritas
\end{abstract}


Penggunaan Dana Desa Kemendes PDTT. Alokasi dan realokasi belanja juga harus diikuti Peraturan Bupati. Integrasinya dalam aplikasi Sistem Keuangan Desa (Siskeudes) BPKP dan Sistem Informasi Pembangunan Desa (SiPeDe) Kemendes PDTT, cukup menimalisir kekeliruan dan potensi kecurangan. Sayangnya hal ini masih kurang didukung peraturan transparansi untuk evaluasi dari Kemenkominfo.

Kata Kunci: Transparansi, Akuntabilitas, Konvergensi Peraturan, Pencegahan Kecurangan Dana Desa.

\section{PENDAHULUAN}

Transparansi dan akuntabilitas keuangan desa merupakan topik yang banyak disorot. Hal ini dikarenakan seringnya terjadi kekeliruan yang cukup fatal, hingga kecurangan keuangan, yang dilakukan oleh aparat pengelola keuangan desa. Padahal pemerintah desa dinaungi oleh 4 kementerian, yaitu Kementerian Desa, Transmigrasi, dan Pembangunan Daerah Tertinggal (Kemendes PDTT), Kementerian Keuangan, Kementerian Dalam Negeri (Kemendagri), serta Kementerian Komunikasi dan Informatika (Kemenkominfo), baik dalam pengelolaan pemerintahan/sumber daya alam/kekayaan desa, hingga pertanggungjawaban dan penginformasian/pengkomunikasian hasil laporan. Berdasarkan harian Kompas (18 Februari 2020), ICW mencatat adanya korupsi pada anggaran desa di tahun 2019 tinggi, lebih tinggi dibandingkan sektor lainnya, yaitu sebanyak 271 kasus korupsi, hingga terjadi kerugian negara Rp 32,3 miliar.

Berdasarkan penelitian sebelumnya oleh Atikah, et al (2019), walaupun Laporan Konsolidasi Realisasi APBDesa menjadi lampiran Laporan Keuangan Pemerintah Daerah (LKPD), namun menghadapi ratusan desa dengan beragam kompleksitas tipe dan laporan, verifikator kabupaten/kota yang terbatas jumlahnya tidak dapat benar-benar secara total memverifikasi laporan keuangan desa, terlebih setelah adanya Peraturan Menteri Dalam Negeri (Permendagri) Nomor 20 Tahun 2018 dengan adanya Laporan Realisasi Kegiatan. Terlebih saat ini dengan keharusan melakukan realokasi anggaran Dana Desa ke Bantuan Langsung Tunai (BLT) berdasarkan PMK Nomor 50/PMK.07/2020, akibat adanya Covid-19 dan stunting masyarakat desa.

Padahal berdasarkan penelitian Atikah, et al (2019) di desa di Kabupaten Lombok Barat, walaupun sudah banyak desa yang menggunakan Online Monitoring Sistem Perbendaharaan dan Anggaran Negara (selanjutnya disingkat OM-SPAN) dalam pengelolaan keuangan desa (dari perencanaan penganggaran, hingga pelaporan), namun ada beberapa desa yang masih menggunakan sistem offline untuk melaporkan data ke DPMD, karena lokasi desa di Kabupaten Lombok Barat yang terpencar, bahkan beberapa desa sulit dijangkau.

Masih berdasarkan penelitian Atikah, et al (2019), selain lokasi desa yang terpencar hingga kesulitan sinyal, kemampuan aparat pengelola keuangan desa yang berbeda-beda juga menyebabkan verifikasi belum dapat total dilakukan secara digital, masih setengah sec ara manual, karena tingkat kekeliruan yang berbeda-beda. Hal ini terutama terjadi dalam tahap pembuatan program dan anggaran dalam perencanaan dan penganggaran keuangan desa.

Berdasarkan observasi peneliti, hal ini juga disebabkan pembaruan aplikasi Siskeudes yang terjadi beberapa kali, terutama karena perubahan peraturan, dengan adanya realokasi anggaran Dana Desa akibat Covid-19. Oleh karena itu, peneliti menduga bahwa hal ini mengakibatkan semakin kompleksnya peraturan dari 4 kementerian yang harus dipahami oleh aparat pengelola keuangan desa, belum lagi ditambah data dari Kementerian Sosial, terkait masyarakat miskin yang berhak menerima BLT.

Kebanyakan kasus yang diduga fraud juga kadangkala agak membingungkan, karena kadangkala para aparat tidak berniat curang, namun lebih banyak tidak tahu mengenai peraturan yang kompleks dari 4 kementerian. 
Sebagai kementerian utama yang membawahi pemerintah desa dan daerah tertinggal dari segi program, pada tahun 2020, Kementerian Desa, Transmigrasi, dan Pembangunan Daerah Tertinggal (PDT) telah mengeluarkan Peraturan Menteri Desa, Pembangunan Daerah Tertinggal, dan Transmigrasi Republik Indonesia Nomor 11 Tahun 2019 untuk menjadi pedoman prioritas Dana Desa tahun 2020. Dalam peraturan ini, pada 2020, Dana Desa diarahkan untuk: (a) peningkatan kualitas hidup;(b) peningkatan kesejahteraan, (c) penanggulangan kemiskinan; dan (d) peningkatan pelayanan publik. Pembuatan program juga tergantung pada tipologi desa dan tingkat perkembangan desa Indeks Desa Membangun (IDM). Bahkan sebagaimana telah dijelaskan sebelumnya, perencanaan dan penganggaran Dana Desa juga harus bersumber dari banyak sumber, yaitu dari Kemendes PDTT (data Indeks Desa Membangun), Kementerian Dalam Negeri (terkait jumlah desa dan jumlah penduduk), BPS (luas wilayah desa dan Indeks Kemahalan Konstruksi-Indeks Kesulitan Geografis), dipadukan dengan Kementerian Sosial (jumlah penduduk miskin desa).

Belum lagi anggaran dipadukan dengan konsep Paket Kegiatan yang digunakan sejak 2019. Padahal pada tahun 2020, arah peraturan juga terkait dengan pelayanan publik untuk pencegahan stunting dan penanggulangan Covid-19, melalui realokasi anggaran belanja desa, yang mengkaitkan dengan penanggulangan dari efek bencana alam sebagai belanja tidak terduga. Kesemua hal ini, harus didukung dengan keterbukaan kepada masyarakat desa, mulai perencanaan, baik melalui musyawarah desa, hingga pelaporan ketercapaian program akhir pemerintah desa yang dibiayai dengan anggaran Dana Desa. Berdasarkan hal itu, sinergi antar kementerian, dan sinergi kementerian dengan eksekutif di daerah, terutama Kementerian Pembangunan Desa dan Daerah Tertinggal sebagai pihak utama yang membawahi DPMD dan pemerintah desa sangat diperlukan.

Dalam hal pencegahan fraud dengan penggunaan Siskeudes yang terus di- update oleh BPKP, pada awal Januari 2020, terjadi peralihan data antar versi dan penyesuaian mekanisme ke Siskeudes V2.0 R.0.2. Hal ini cukup krusial kaitannya dengan akuntabilitas, karena walaupun sudah ada interkoneksi dengan OM-SPAN, termasuk upgrade SML/SQL, namun berdasarkan hasil penelitian Atikah, et al (2019) sebelumnya, tidak semua pemerintah desa sudah mencapai prinsip dasar akuntabilitas. Bahkan penelitian Satriajaya, et al (2017) juga menemukan turbulensi dan kleptokrasi dalam pengelolaan keuangan desa melalui metode fenomenologi- hermeneutika. Namun penyimpangan dalam pengelolaan keuangan desa dapat terjadi karena pelaku menerima tekanan.

Penelitian ini bertujuan menganalisis kebijakan transparansi maupun akuntabilitas dari 4 kementerian yang membawahi pemerintah desa, ditambah dengan perspektif verifikator DPMD kabupaten. Berdasarkan analisis isi, penelitian ini bermanfaat untuk menganalisis sinergi antar peraturan kementerian, sebagai bentuk kebijakan untuk mencegah penyelewengan atas Dana Desa.

\section{METODE PENELITIAN}

Penelitian ini merupakan penelitian kebijakan substansi. Jenis penelitian yang digunakan yaitu deskriptif analitis, untuk menganalisis konvergensi antara peraturan terkait transparansi dan akuntabilitas yang dibuat oleh 4 kementerian yang menaungi desa, yaitu Kementerian Desa, Transmigrasi, dan Pembangunan Daerah Tertinggal (Kemendes PDTT), Kementerian Keuangan, Kementerian Dalam Negeri (Kemendagri), serta Kementerian Komunikasi dan Informatika (Kemenkominfo).

Terkait dengan kebijakan publik, berdasarkan Dunn (2014:5), analisis kebijakan publik diawali dengan pendeteksian masalah terkait fenomena yang terjadi. Tahap awal pendeteksian masalah ini telah dilakukan pada penelitian Atikah, et al (2019). 
Oleh karena penyebab fenomena permasalahan keuangan di desa belum total terdeteksi, tahap ini masih akan dilanjutkan dalam penelitian ini. Pada penelitian ini, luarannya yaitu pendeteksian apakah kebijakan antar 4 kementerian yang membawahi desa sudah konvergen atau belum. Metode yang digunakan yaitu analisis telaah isi peraturan.

Lokasi penelitian meliputi 4 Kabupaten se-Pulau Lombok. Obyek penelitian ini yaitu kebijakan kementerian terkait pengelolaan keuangan desa, yang diturunkan dalam Peraturan Kementerian, Instruksi Presiden, dan Surat Edaran.

Berdasarkan obyek tersebut, analisis isi peraturan dilakukan melalui telaah pustaka peraturan kementerian yang terkait dengan keuangan desa, termasuk peraturan bupati. Peraturan bupati juga digali melalui wawancara dengan verifikator dari Dinas Pemberdayaan Masyarakat dan Desa (DPMD) se-Pulau Lombok.

\section{HASIL DAN PEMBAHASAN}

Kesemua peraturan keuangan desa terpusat dari Permendagri Nomor 20 Tahun 2018 (Bagian IV Pasal 31 sampai Pasal 31 sampai Pasal 41) jo. Peraturan Menteri Dalam Negeri No. 113 Tahun 2014. Terkait akuntabilitas, karena dinaungi oleh 3 kementerian, penelitian ini berfokus pada akuntabilitas kebijakan atas peraturan 3 kementerian. Berikut ringkasan dan analisis peraturan dasar akuntabilitas yang menaungi desa, terkait program atas pengelolaan keuangan desa, dari 3 kementerian (Kementerian Dalam Negeri, Kementerian Keuangan, dan Kemendes PDTT):

Dana Desa sebagai dana yang diberikan dari pemerintah pusat ke pemerintah desa, ditujukan untuk pembangunan di desa, mengacu ke Sustainable Development Goals ( $S D G$ 's) Desa. Oleh karena diberikan oleh pemerintah pusat, kinerja pengelolaan keuangan, serta pelaporan hasil pembangunan ini menjadi salah satu aspek akuntabilitas, yang diperhatikan untuk persentase alokasi Dana Desa, terutama alokasi kinerjanya. Pelaporan ini juga mengarah pada pencegahan kecurangan/fraud Dana Desa.

Dasar pertama dari alokasi Dana Desa adalah Alokasi Dasar, berdasarkan PMK No.205/PMK.07/2019, yang ketentuannya masih berlaku hingga PMK No.50/PMK.07/2020. Atas alokasi dasar ini, Kementerian Keuangan telah menentukan sejumlah indikator yang harus dipenuhi oleh sebuah desa, untuk mendapatkan dana Alokasi Kinerja. Pada pasal 6 PMK No.205 Tahun 2019, desa dengan kinerja terbaik adalah desa yang dipilih sebanyak $10 \%$ dari jumlah desa yang memiliki hasil penilaian kinerja terbaik. Misalnya, jika kabupaten memiliki desa berjumlah antara 0 sampai 100, maka penerima alokasi kinerja sebanyak $11 \%$ dari jumlah desa (Pasal 12 ayat 2 PMK No.205/PMK.07/2019). Untuk desa dengan kinerja terbaik (PMK No.205/PMK.07/2019 Pasal 6 Ayat 5, Pagu Alokasi Kinerja yang diberikan kepada desa dengan kinerja terbaik, dihitung sebesar 1,5\% dari anggaran Dana Desa.

Penilaian atas kinerja desa ini didasarkan pada empat indikator, yaitu pengelolaan keuangan desa, pengelolaan Dana Desa, capaian keluaran (output) Dana Desa, dan capaian hasil (outcome) pembangunan desa. Rumusnya pada Pasal 12 ayat 3 sampai ayat 8, pada peraturan yang sama.

Lebih lanjut, terkait pengelolaan Dana Desa, mulai dari perhitungan rasio alokasi untuk setiap desa, dokumen yang digunakan, dan mekanisme penyaluran dari Rekening Kas Umum Negara (selanjutnya disingkat RKUN) ke Rekening Kas Umum Daerah (selanjutnya disingkat RKUD), untuk kemudian dialokasikan ke Rekening Kas Desa (selanjutnya disingkat RKD), tertuang dalam PMK Nomor 156/PMK.07/2020 jo. PMK Nomor 50/PMK.07/2020 jo. PMK Nomor40/PMK.07/2020 jo. PMK Nomor 205/PMK.07/2019 jo. PMK Nomor 193/PMK.07/2018. Sementara untuk desa yang berstatus tertinggal dan sangat tertinggal (PMK No.205/PMK.07/2019), akan memperoleh alokasi Dana Desa sesuai 
statusnya ini, tidak hanya untuk memperbaiki bidang ekonomi, namun juga sosial dan lingkungan (sesuai Indeks Desa Membangun, IDM, dari Kemendes PDTT).

Sejalan dengan hal ini, terkait peraturan dari Kemendes PDTT No.16/2018 Tentang Prioritas Penggunaan Dana Desa 2019 Bab III Pasal 4, penggunaan Dana Desa diprioritaskan untuk membiayai pelaksanaan program dan kegiatan di bidang Pembangunan Desa dan Pemberdayaan Masyarakat Desa, termasuk yang bersifat lintas bidang. Tujuannya lebih ke peningkatan kualitas hidup, penanggulangan kemiskinan, dan peningkatan pelayanan publik di tingkat Desa.

Berdasarkan peraturan di atas, untuk besar alokasi Dana Desa yang diberikan dalam tahap penganggaran, terbagi menjadi 4 bagian yaitu: (a) Alokasi Dasar, (b) Alokasi Afirmasi, (c) Alokasi Kinerja, dan (d) Alokasi Formula. Rumusnya yaitu:

a. Alokasi Dasar, yaitu alokasi minimal Dana Desa yang akan diterima oleh setiap Desa secara merata, dihitung berdasarkan persentase tertentu dari anggaran Dana Desa yang dibagi dengan jumlah desa secara nasional.

b. Alokasi Afirmasi, yaitu alokasi yang dihitung dengan memperhatikan status Desa tertinggal dan Desa sangat tertinggal, yang memiliki jumlah penduduk miskin tinggi. PMK ini juga terkait dengan Permendes PDTT tentang

c. Alokasi Kinerja, yaitu alokasi yang diberikan kepada desa yang memiliki hasil penilaian kinerja terbaik. Dalam hal ini, Kementerian Keuangan telah menentukan sejumlah indikator yang harus dipenuhi oleh sebuah desa untuk mendapatkan dana alokasi kinerja ini. Pada pasal 6 Peraturan Menteri Keuangan (PMK) No.205/PMK.07/2019 Bab IV Pasal 6 Ayat 6, desa dengan kinerja terbaik adalah desa yang dipilih sebanyak $10 \%$ dari jumlah desa yang memiliki hasil penilaian kinerja terbaik. Berikut rumus bobot perhitungan kinerja, untuk penentuan predikat desa dengan kinerja terbaik:

Kinerja Desa $=(20 \%$ x Pengelolaan Keuangan Desa $)+(20 \%$ x Pengelolaan Dana Desa $)+$ $(25 \%$ x Capaian Keluaran Dana Desa $)+(35 \%$ x Capaian Hasil Dana Desa $)$

d. Alokasi Formula, yaitu alokasi yang dihitung dengan memperhatikan jumlah penduduk Desa, angka kemiskinan Desa, luas wilayah Desa, dan tingkat kesulitan geografis (IKG) Desa setiap kabupaten. Rumusnya yaitu:

AF Desa $=\left(0,10 X Z_{1}\right)+\left(0,50 X Z_{2}\right)+\left(0,15 X Z_{3}\right)+\left(0,25 \times Z_{4}\right)$

Keterangan:

AF Desa: Alokasi Formula setiap Desa

Z1: rasio jumlah penduduk setiap Desa terhadap total penduduk Desa

$\mathrm{Z}_{2}$ : rasio jumlah penduduk miskin setiap Desa dengan total penduduk miskin Desa

Z3: rasio luas wilayah setiap Desa terhadap total luas wilayah Desa

Z4: rasio IKG setiap Desa terhadap total IKG Desa

Sebagaimana penelitian Rakhmawati (November, 2020), kendalanya, jika beragam indikator dari data dihubungkan dengan aplikasi Prodeskel dari Kemendagri, baik untuk pendataan jumlah penduduk Desa, angka kemiskinan Desa, luas wilayah Desa, dan IKG, serta IKK (Indeks Kemahalan Konstruksi) kabupaten, aparat pengelola keuangan desa maupun pendamping desa seringkali terkendala dan kesulitan, karena kurangnya jumlah tenaga/sumber daya, koneksi data ke dinas lain (termasuk BPS dan BPN), geografis desa, dan kondisi desa. Akibatnya, data tidak bisa segera terupdate, sehingga penghitungan rincian Dana Desa menggunakan data dari rincian Dana Desa tahun anggaran sebelumnya. 
Belum lagi, peraturan dari aplikasi ini harus terkoneksi dengan aplikasi untuk menghitung Indeks Desa Membangun (IDM), dari Kemendes PDTT, berdasarkan Permendes PDTT No.2/2016. Hal ini akan mempengaruhi intervensi Kementerian Keuangan, baik dari segi anggaran maupun kebijakan pembangunan desa.

Dalam Peraturan Bupati, berikut peraturan perencanaan, penganggaran, dan alokasi Dana Desa, dari setiap kabupaten:

a. Untuk Kabupaten Lombok Barat, peraturannya yaitu Peraturan Bupati Lombok Barat No. 11 Tahun 2019 Tentang Prioritas Penggunaan Dana Desa 2019 dan Peraturan Bupati Lombok Barat No. 8 Tahun 2019 Tentang Tata Cara Pembagian dan Penetapan Rincian Dana Desa 2019.

b. Untuk Kabupaten Lombok Tengah, peraturannya yaitu Peraturan Bupati Lombok Tengah No. 2 Tahun 2019 Tentang Tata Cara Pembagian, Penyaluran, Penggunaan, Pelaporan, dan Penetapan Rincian Dana Desa Setiap Desa di Kabupaten Lombok Tengah Tahun Anggaran 2019, dan Peraturan Bupati Lombok Tengah Nomor 37 Tahun 2019 Tentang Tata Cara Pembagian, Penyaluran, Penggunaan, Pelaporan, dan Penetapan Rincian Dana Desa Setiap Desa di Kabupaten Lombok Tengah Tahun Anggaran 2020.

c. Untuk Kabupaten Lombok Utara, peraturannya yaitu Peraturan Bupati Lombok Utara No. 12 Tahun 2019 Tentang Pengelolaan Keuangan Desa, Peraturan Bupati Lombok Utara No. 28 Tahun 2019 Tentang Pedoman Penyusunan APBDesa Tahun 2020, dan Peraturan Bupati Lombok Utara No. 30 Tahun 2019 Tentang Tata Cara Pembagian dan Penetapan Rincian Dana Desa Setiap Desa Tahun 2020. Terutama karena pada pertengahan tahun 2020, ada pemecahan desa menjadi bertambah 10 desa, sehingga untuk mengawali tahun berikutnya, perlu pemetaan aset desa, untuk laporan posisi keuangan desa.

d. Untuk Kabupaten Lombok Timur, peraturannya yaitu Peraturan Bupati Lombok Timur No. 44 Tahun 2019 Tentang Pedoman Penyusunan APB Desa TA.2019

Alokasi ke arah bidang Pembangunan Desa dan Pemberdayaan Masyarakat Desa juga berlaku hingga 2020, melalui PMK No.40/PMK.07/2020, yang dijalankan oleh setiap kabupaten melalui Peraturan Bupati atas Prioritas Penggunaan Dana Desa. Namun sejalan dengan Peraturan Kemendes PDTT, walaupun penggunaan Dana Desa tetap diprioritaskan untuk membiayai pembangunan dan pemberdayaan masyarakat, sebagaimana tertuang dalam Rencana Kerja Pemerintah (RKP) Desa, prioritas penggunaan Dana Desa juga direalokasi pada belanja dan bantuan untuk menanggulangi dampak ekonomi atas pandemi COVID19, salah satunya melalui jaring pengaman sosial di Desa. Peraturan dari Kementerian Keuangan ini mengikuti perubahan Peraturan Kemendes PDTT, yang mengubah alokasi Pengelolaan Dana Desa hingga 3 kali.

Peraturan tersebut yaitu Permendes PDTT No.14/2020 jo. Permendes No.7/2020 jo. Permendes PDTT No.6/2020 jo. Permendes PDTT No.11/2020 tentang Prioritas Penggunaan Dana Desa. Pada PMK, adanya BLT ini diwujudkan melalui PMK No.40/PMK.07/2020, dengan adanya penambahan 1 pasal (Pasal 30) tentang Rekening Kas Desa dan Bantuan Langsung Tunai Desa, serta adanya penyesuaian Laporan Realisasi Penyerapan dan Capaian Keluaran Dana Desa, dan penambahan 1 laporan yaitu Laporan Pelaksanaan Bantuan Langsung Tunai Desa (format terlampir). Hal ini dimaksudkan untuk meminimalisir kemungkinan kecurangan (fraud), karena realokasi anggaran, hingga pelaksanaan, dari mulai sebelum, apalagi setelah adanya BLT, tetap ada.

Untuk 2021 sendiri, prioritas penggunaan Dana Desa didasarkan Permendes PDTT No. 13/2020 Pasal 5, yang menyebutkan prioritas diarahkan ke program dan/atau kegiatan percepatan pencapaian SDGs Desa. Selain itu, program prioritas nasional juga mengacu ke 
pengembangan teknologi informasi dan komunikasi untuk memperluas kemitraan desa, dan pengembangan desa wisata serta desa inklusif.

Terkait review isi peraturan kementerian untuk mencapai akuntabilitas pelaksanaan, sesuai dengan Permendagri Nomor 20 Tahun 2018 Pasal 50 sampai Pasal 67, pelaksanaan dan penatausahaan keuangan desa diatur dengan beragam dokumen dan catatan yang harus dibuat oleh pengelola keuangan desa. Sebagaimana telah dijelaskan di atas, alokasi anggaran Dana Desa terbagi menjadi 4 jenis alokasi anggaran, yaitu Alokasi Dasar, Alokasi Afirmasi, Alokasi Kinerja, dan Alokasi Formula. Oleh karena itu, pelaksanaannya pun harus mengacu pada program dalam anggaran tiap alokasi ini.

Jika dikaitkan dengan pergerakan BLT, pergerakan PMK juga didasarkan Permendagri No. 20/2018 Pasal 41 tentang pergeseran objek belanja, yang mengakibatkan adanya PMK 14/PMK.07/2020 dan PMK 13/PMK.07/2020. Perubahannya dari PMK No.40/PMK 07/2020 terkait BLT yaitu:

a. Masa penyaluran BLT Dana Desa 9 (sembilan) bulan terhitung sejak April 2020. b. Berdasarkan PMK No.40/PMK.07/2020 yang dikeluarkan April 2020, besaran BLT dana desa per bulan sebesar Rp 600.000 per keluarga untuk 3 (tiga) bulan pertama (April, Mei, dan Juni).

c. Berdasarkan PMK No.50/PMK.07/2020 yang dikeluarkan Mei 2020, besaran BLT dana desa per bulan menjadi turun sebesar Rp 300.000 per keluarga untuk 3 (tiga) bulan kedua (Juli, Agustus, dan September).

d. Berdasarkan PMK 156/PMK.07/2020 yang dikeluarkan Oktober 2020, besaran BLT dana desa per bulan sebesar Rp 300.000 per keluarga untuk 3 (tiga) bulan ketiga (Oktober, November, dan Desember).

BLT di atas dapat disalurkan sepanjang Dana Desa tahun anggaran 2020 masih tersedia. Terjadi pula perubahan pagu anggaran berdasarkan PMK No. 145/PMK.07/2020 jo. PMK No.35/PMK.07/2020 tentang Pengelolaan TKDD TA.2020.

Untuk review peraturan terkait akuntabilitas pelaporan, pada tahap pelaporan, sumbernya tetap Permendagri No. 20/2018 Bagian IV Pasal 68 sampai Pasal 73, tentang Pelaporan dan Pertanggungjawaban. Hal ini juga bermuara pada Siskeudes yang dikeluarkan oleh Badan Pengawas Keuangan dan Pembangunan (BPKP) di bawah Kementerian Dalam Negeri. Laporan yang harus dibuat desa meliputi Laporan Realisasi APB Desa dan Catatan atas Laporan Keuangan.

Selanjutnya, peraturan ini dituangkan Kementerian Keuangan dalam PMK No. 205/PMK.07/2019. Kemudian berdasarkan PMK No. 40/PMK.07/2020 Pasal 24, penyaluran Dana Desa sebagaimana dimaksud dalam Pasal 23 ayat (4) dilaksanakan setelah Kepala KPPN menerima dokumen persyaratan penyaluran dari bupati, dengan ketentuan:

a. Tahap I berupa Peraturan Bupati mengenai tata cara pembagian dan penetapan rincian Dana Desa setiap Desa, Peraturan Desa mengenai APBDes, surat kuasa pemindahbukuan Dana Desa.

b. Tahap II berupa laporan realisasi penyerapan dan capaian keluaran Dana Desa dari tahun anggaran sebelumnya atau periode tahapan sebelumnya.

c. Capaian keluaran dihitung berdasarkan rata-rata persentase capaian keluaran dari seluruh kegiatan setiap desa, dan Laporan Realisasi Penyerapan dan Capaian Keluaran dilakukan sesuai dengan tabel referensi data bidang, kegiatan, uraian keluaran, volume keluaran, satuan keluaran, dan capaian keluaran (format pada Lampiran 1). 
Dalam Siskeudes versi 2, peraturan kedua kementerian ini sudah tercakup dalam aplikasi, karena aplikasi yang dibangun oleh BPKP di bawah Kementerian Dalam Negeri juga sudah terkoneksi dengan OM-SPAN Kementerian Keuangan, untuk menarik data Laporan Realisasi APB Desa dan Capaian Keluaran, yang digunakan oleh Kementerian Keuangan untuk memberikan besar alokasi Dana Desa untuk periode berikutnya.

Selain itu, penilaian kinerja juga dilakukan melalui aplikasi SiPeDe (Sistem Informasi Pembangunan Desa) dari Kemendes PDTT. Berdasarkan penelitian Rakhmawati (November, 2020), aplikasi ini baru akan terintegrasi dengan OM-SPAN Siskeudes tahun ini.

Terakhir, terkait analisis isi peraturan Kemenkominfo dengan hasil analisis isi akuntabilitas yang telah dijelaskan di atas, keterkaitannya yaitu pada evaluasi pelaksanaan asas transparansi atas keuangan desa. Keterbukaan informasi antara lain melalui musyawarah desa, baliho, papan pengumuman, maupun website desa. Namun berdasarkan telaah pustaka peneliti, peraturan yang digunakan Kementerian Komunikasi dan Informatika terkait transparansi ini masih berbasis Instruksi Presiden Republik Indonesia Nomor 9 Tahun 2015 Tentang Pengelolaan Komunikasi Publik. Dengan demikian, dari segi perubahan peraturan, sepengetahuan peneliti, masih agak minim, untuk mengikuti akuntabilitas.

Dari segi konvergensi, berdasarkan hasil telaah pustaka dan wawancara dengan Dinas Pemberdayaan Masyarakat dan Desa (DPMD) Kabupaten, peneliti menyimpulkan bahwa walaupun antar peraturan kementerian, baik Kementerian Dalam Negeri, Kementerian Desa, Pembangunan Daerah Tertinggal, dan Transmigrasi, serta Kementerian Keuangan sudah cukup terintegrasi. Jika dirunut ke atas, pusat peraturannya adalah Peraturan Pemerintah (PP) Nomor 11 Tahun 2019 Tentang Perubahan Kedua atas PP Nomor 43 Tahun 2014 Tentang Peraturan Pelaksanaan UU Nomor 6 Tahun 2014 Tentang Desa, dan Peraturan Menteri Dalam Negeri (Permendagri) Nomor 20 Tahun 2018. Kemudian dari basis tersebut, turunannya adalah peraturan dari Kemendes PDTT menyangkut prioritas penggunaan Dana Desa (disesuaikan pula dari angka pada Indeks Desa Membangun), sementara peraturan pelaksanaan dan evaluasinya dikeluarkan oleh Kementerian Keuangan.

Namun karena perubahannya yang berkali-kali pada 2020 (sampai 3 kali perubahan) akibat bencana non-alam (Covid-19), perubahan ini juga harus diikuti pula dengan perubahan Peraturan Bupati untuk realokasi belanja. Hal ini cukup merepotkan bagi daerah, karena walaupun perubahan tersebut tetap mengacu pada Permendagri No. 20/ 2018 Tentang Pengelolaan Keuangan Desa, namun perubahan Permendes PDTT yang sampai 3 kali tahun ini, diikuti pula oleh Kementerian Keuangan yang menerbitkan PMK. Perubahan dalam peraturan kemudian menimbulkan perubahan pula dalam input belanja dan alokasinya, dalam Siskeudes, yang dijalankan oleh tiap operator desa (Kaur Keuangan), dan diverifikasi oleh verifikator DPMD Kabupaten.

Efeknya, penyaluran Dana Desa dan alokasi kembali (realokasi) untuk belanja, mengakibatkan pengelola keuangan desa dari pemerintah desa dan DPMD juga cukup kerepotan dalam pelaksanaannya, hingga muncul program Percepatan Penyaluran Dana Desa pada Oktober dan November 2020.

Setiap proses pengelolaan keuangan desa, yang seharusnya berbasis kinerja, dan diinput capaiannya, dengan integrasi antar kementerian, juga belum cukup terintegrasi. Hal ini ditemukan berdasarkan penelitian Rakhmawati (November 2020), yang menemukan bahwa input data profil desa di Prodeskel dari aplikasi Kementerian Dalam Negeri, belum menjadi input untuk perencanaan dan penganggaran di aplikasi output Indeks Desa Membangun (IDM) dari Kemendes PDTT. Input ini juga masih terpecah dari anggaran dan rencana dari Siskeudes (Sistem Keuangan Desa), aplikasi dari BPKP, yang berada di bawah Kementerian Dalam Negeri, dan ditarik laporannya oleh Kementerian Keuangan melalui OM-SPAN. 
Dengan demikian, walaupun dari segi peraturan sudah cukup terintegrasi, namun dari segi aplikasi, 3 kementerian tersebut masih belum cukup terintegrasi. Namun, walaupun dari segi aplikasi belum cukup terintegrasi, adanya PMK yang mengatur pelaksanaan termin (termasuk dalam Siskeudes BPKP), serta peraturan Capaian Keluaran Dana Desa untuk pencairan Dana Desa berikutnya, menjadikan potensi fraud maupun kekeliruan di pemerintah desa cukup dapat diminimalisir.

Hasil penelitian ini sinkron dengan penelitian Mardianis (2019), yang menemukan bahwa walaupun implementasi Siskeudes secara online manfaatnya sangat dirasakan oleh Pemerintah Desa dalam membantu tertibnya proses pengelolaan keuangan desa, namun regulasi dan prosedur yang masih manual dan belum sinkron dengan sistem keuangan yang sudah online, menjadi masalah. Meskipun demikian, jika pemerintah desa lebih serius dalam penyajian laporan pertanggungjawabannya, hal ini kemungkinan besar dapat diatasi. Hal ini ditilik dari penelitian Jaya (2019), yang menemukan bahwa pemerintah desa Kebondalem Kidul di Kabupaten Klaten, Jawa Tengah, yang serius dalam penyajian dan persiapan laporan pertanggungjawabannya, menjadi baik dalam penyusunan laporan pertanggungjawabannya, dalam pos-pos dalam Laporan Realisasi APBD, sesuai dengan Permendagri No. 113 tahun 2014.

Sementara itu, terkait dengan transparansi, oleh karena peneliti hanya memperoleh sedikit peraturan dari Kementerian Komunikasi dan Informatika, peneliti menganggap kurangnya peraturan (dari sumber telaah pustaka ini) mengakibatkan evaluasi atas transparansi dalam pelaporan dan pertanggungjawaban desa, menjadi kurang. Update desa terhadap baliho, website, tampaknya tidak begitu cukup dievaluasi oleh dinas dan kementerian juga, karena Dana Desa yang sudah cukup habis untuk membiayai pembangunan dan pemberdayaan masyarakat desa. Pada 2021, program prioritas nasional untuk penganggaran 2021 kembali mengacu ke pengembangan teknologi informasi dan komunikasi untuk memperluas kemitraan desa, serta pengembangan desa wisata.

Dari segi analisa kebijakan, karena kesemua peraturan kementerian, baik Kementerian Dalam Negeri, Kementerian Desa, Pembangunan Daerah Tertinggal, dan Transmigrasi, serta Kementerian Keuangan, dan Kementerian Komunikasi dan Informatika sudah mengacu ke Peraturan Pemerintah Nomor 11 Tahun 2019, maka dari segi model konvergensi, kesemuanya sudah cukup terintegrasi. Akan tetapi, kemampuan perumus kebijakan untuk lebih visioner, agar dapat merumuskan kebijakan jauh ke depan. Khusus untuk Kementerian Komunikasi dan Informatika, juga diharapkan lebih visioner dalam mengkompilasi standar digital untuk desa, sehingga lebih bisa merumuskan peraturan transparansi desa, sesuai letak geografis desa juga. Selain itu, analisa apakah setiap desa sudah transparan atau belum, diharapkan juga dikaitkan oleh Kementerian Komunikasi dan Informatika dengan basis kinerja, untuk meminimalisir potensi kecurangan (fraud) atas pengelolaan keuangan Dana Desa.

\section{SIMPULAN}

Dari segi konvergensi, berdasarkan hasil analisis isi dari telaah pustaka dan wawancara dengan Dinas Pemberdayaan Masyarakat dan Desa (DPMD) Kabupaten, peneliti menyimpulkan bahwa antar peraturan akuntabilitas dari kementerian, baik Kementerian Dalam Negeri, Kementerian Desa, Pembangunan Daerah Tertinggal, dan Transmigrasi, serta Kementerian Keuangan sudah cukup terintegrasi. Dasarnya adalah dari Peraturan Pemerintah (PP) Nomor 11 Tahun 2019 Tentang Perubahan Kedua atas PP Nomor 43 Tahun 2014 Tentang Peraturan Pelaksanaan UU Nomor 6 Tahun 2014 Tentang Desa, dan Peraturan Menteri Dalam Negeri (Permendagri) Nomor 20 Tahun 2018. Berdasarkan kedua sumber 
tersebut, turunannya adalah peraturan dari Kemendes PDTT menyangkut prioritas penggunaan Dana Desa (disesuaikan pula dari angka pada Indeks Desa Membangun), sementara peraturan pelaksanaan dan evaluasi atas pelaksanaan Dana Desa dikeluarkan oleh Kementerian Keuangan. Perubahan ini juga sudah diikuti dengan perubahan Peraturan Bupati untuk realokasi belanja karena Covid-19.

Integrasi peraturan ini, yang diwujudkan dalam aplikasi Sistem Keuangan Desa (Siskeudes) dari BPKP, yang berada di bawah Kementerian Dalam Negeri, cukup dapat meminimalisir kekeliruan maupun kecurangan (fraud) di desa. Hal ini juga sudah didukung oleh aplikasi Sistem Informasi Pembangunan Desa (SiPeDe) dari Kemendes PDTT. Namun hal ini masih kurang didukung dengan transparansi, karena minimnya peraturan dan evaluasi dari Kementerian Komunikasi dan Informatika.

Atas hasil penelitian ini, peneliti menyarankan agar dibangun sinergi antar kementerian terkait, agar kebijakan yang dikeluarkan sinkron dan saling menguatkan. Sinergi tersebut hendaknya dibangun dengan komunikasi, komitmen untuk bekerja sama, dan koordinasi, sebelum mengesahkan peraturan. Antar kementerian koordinator diharapkan juga dapat saling bersinergi.

Peneliti menganggap bahwa hal ini juga dibutuhkan, agar pemerintah kabupaten dapat menghasilkan peraturan daerah maupun peraturan bupati, dengan sinkronisasi antar peraturan kementerian yang berbeda. Hal serupa juga telah dikemukakan oleh Widodo, et al (2017) dan Widodo, et al (2019), bahwa sinkronisasi, koordinasi, dan kerjasama yang kompak antar kementerian/lembaga pemerintah pusat dan daerah sangat dibutuhkan, untuk memastikan efektivitas implementasi pengelolaan keuangan desa. Namun terkait konvergensi dengan peraturan bupati, masih perlu dilakukan penelitian lebih lanjut, dengan periode yang lebih panjang.

\section{DAFTAR PUSTAKA}

Atikah, S., Hendri, S., \& Rakhmawati, I. (2019). Implementasi Pendapatan, Belanja dan Pelaporan Keuangan Desa. Jurnal Riset Akuntansi Aksioma, 18(1), 84-112. https://doi.org/10.29303/aksioma.v18i1.67.

Atikah, S, Rakhmawati, I., Astuti, B.R.D. \& Nabila, T.D. (2019). Evaluasi Sistem Aplikasi Keuangan Desa. Unpublished. Laporan Penelitian Universitas Mataram.

Dunn, W.N. (2014). Public Policy Analysis Fifth Edition. (PDF) Public Policy Analysis (researchgate.net).

Hasniati. (2016). Model Akuntabilitas Pengelolaan Dana Desa. Universitas Hasanuddin, Jurnal Analisis Kebijakan dan Pelayanan Publik, 2(1), Juni 2016. http://journal.unhas.ac.id/index.php/jakpp/article/view/1519.

Jaya, I Made Laut Mertha. (2019). Perlakuan Akuntansi Sektor Publik Desa. Gorontalo Accounting Journal, 2(1), April 2019. (PDF) ACCOUNTING TREATMENT IN VILLAGE PUBLIC SECTOR PERLAKUAN AKUNTANSI SEKTOR PUBLIK DESA (researchgate.net).

Kementerian Dalam Negeri Republik Indonesia. 2018. Peraturan Menteri Dalam Negeri Nomor 20 Tahun 2018 Tentang Pengelolaan Keuangan Desa. Jakarta: Kementerian Dalam Negeri Republik Indonesia.

Kementerian Desa, Pembangunan Daerah Tertinggal, dan Transmigrasi Republik Indonesia. (2019). Peraturan Menteri Desa, Pembangunan Daerah Tertinggal, dan Transmigrasi Republik Indonesia Nomor 19 Tahun 2019 Tentang Pelimpahan dan Penugasan Urusan Pemerintahan Bidang Pemberdayaan Masyarakat dan Desa Serta Transmigrasi Tahun Anggaran 2020. Jakarta: Kementerian Desa, Pembangunan Daerah Tertinggal, dan Transmigrasi Republik Indonesia. 
. (2019). Peraturan Menteri Desa, Pembangunan Daerah Tertinggal, dan Transmigrasi Republik Indonesia Nomor 11 Tahun 2019 Tentang Prioritas Penggunaan Dana Desa 2020. Jakarta: Kementerian Desa, Pembangunan Daerah Tertinggal, dan Transmigrasi Republik Indonesia.

. (2019). Peraturan Menteri Desa, Pembangunan Daerah Tertinggal, dan Transmigrasi Republik Indonesia Nomor 19 Tahun 2019 Tentang Pelimpahan dan Penugasan Urusan Pemerintahan Bidang Pemberdayaan Masyarakat dan Desa Serta Transmigrasi Tahun Anggaran 2020. Jakarta: Kementerian Desa, Pembangunan Daerah Tertinggal, dan Transmigrasi Republik Indonesia.

Kementerian Keuangan. (2017). Peraturan Menteri Keuangan Nomor 199/PMK. 07 /2017 Tentang Tata Cara Pengalokasian Dana Desa Setiap Kabupaten/Kota. Jakarta: Kementerian Keuangan Republik Indonesia.

(2019). Peraturan Menteri Keuangan Nomor 205/PMK.07/2019 Tentang Pengelolaan Dana Desa. Jakarta: Kementerian Keuangan Republik Indonesia.

(2020). Peraturan Menteri Keuangan Nomor 40/PMK.07/2020 Tentang Perubahan atas Peraturan Menteri Keuangan Nomor 205/PMK.07/2019 Tentang Pengelolaan Dana Desa. Jakarta: Kementerian Keuangan Republik Indonesia. . (2020). Peraturan Menteri Keuangan Nomor 50/PMK.07/2020 Tentang Perubahan Kedua atas Peraturan Menteri Keuangan Nomor 205/PMK.07/2019 Tentang Pengelolaan Dana Desa. Jakarta: Kementerian Keuangan Republik Indonesia.

(2020). Peraturan Menteri Keuangan Nomor 156/PMK.07/2020 Tentang Perubahan Ketiga atas Peraturan Menteri Keuangan Nomor 205/PMK.07/2019 Tentang Pengelolaan Dana Desa. Jakarta: Kementerian Keuangan Republik Indonesia.

Kementerian Komunikasi dan Informatika. (2015). Instruksi Presiden Republik Indonesia Nomor 9 Tahun 2015 Tentang Pengelolaan Komunikasi Publik. Jakarta: Kementerian Komunikasi dan Informatika.

Mardianis. (2019). Implementasi Siskeudes Secara Online dan Tsunami Regulasi Keuangan Desa (Studi Desa di Kabupaten Batang Hari Provinsi Jambi). Prosiding. (PDF) Implementasi Siskeudes Secara Online dan Tsunami Regulasi Keuangan Desa (Studi Desa di Kabupaten Batang Hari Provinsi Jambi) (researchgate.net).

Ramadhan, A., Erdianto, K. (2019). Catatan ICW, Kasus Korupsi Dana Desa Terbanyak Muncul pada 2019. https://nasional.kompas.com/read/2020/02/18/19084421/catatan-icw-kasuskorupsi-dana-desa-terbanyak-muncul-pada-2019.

Satriajaya, J, Handajani, L., \& Putra, I N.N.A. (2017). Turbulensi dan Legalisasi Kleptokrasi dalam Pengelolaan Keuangan Desa. Jurnal Akuntansi Multiparadigma-JAMAL, 8(2), http://dx.doi.org/10.18202/jamal.2017.08.7052. .

Widagdo, A.K, Setyorini, E. (2018). Determinans of Intention to Use Village Fund Information System. Jurnal Akuntansi dan Keuangan Indonesia, 15(1), http://jaki.ui.ac.id/index.php/home/article/download/759/759.

Widodo, S, Wibowo, A.P.S. \& Nasution, M. (2017). Mengejar Ketertinggalan : Pembangunan Daerah Tertinggal. https://puskajianggaran.dpr.go.id/produk/indexanalisis-apbn/page/10. 
Rakhmawati, Hendri \& Kartikasari: Kebijakan Transparansi dan...

Widodo, S., Riyono, T. \& Agustiani, F.N.. (2019). Penguatan Sistem Informasi Desa dalam Tata Kelola Desa. https://puskajianggaran.dpr.go.id/produk/index-analisisapbn/page/4. 